\title{
Enrichment Mechanism of the Upper Carboniferous-Lower Permian Transitional Shale in the East Margin of the Ordos Basin, China: Evidence from Geochemical Proxies
}

\author{
Zhifu Wei $\mathbb{D}^{1},{ }^{1}$ Yongli Wang $\mathbb{D},{ }^{1,2}$ Gen Wang $\mathbb{D}^{1},{ }^{1}$ Ting Zhang, ${ }^{1,3}$ Wei He, ${ }^{1,3}$ Xueyun Ma, ${ }^{1,3}$ \\ and Xiaoli Yu $\mathbf{u}^{1,3}$ \\ ${ }^{1}$ Key Laboratory of Petroleum Resources Research, Gansu Province, Northwest Institute of Eco-Environment and Resources, \\ Chinese Academy of Sciences, Lanzhou 730000, China \\ ${ }^{2}$ Key Laboratory of Cenozoic Geology and Environment, Institute of Geology and Geophysics, Chinese Academy of Sciences, \\ Beijing 100029, China \\ ${ }^{3}$ University of Chinese Academy of Sciences, Beijing 100049, China
}

Correspondence should be addressed to Yongli Wang; ylwang@mail.iggcas.ac.cn and Gen Wang; gwang@lzb.ac.cn

Received 25 July 2020; Revised 25 September 2020; Accepted 9 October 2020; Published 6 November 2020

Academic Editor: Paolo Madonia

Copyright (c) 2020 Zhifu Wei et al. This is an open access article distributed under the Creative Commons Attribution License, which permits unrestricted use, distribution, and reproduction in any medium, provided the original work is properly cited.

The organic-rich shale of the Upper Carboniferous-Lower Permian transition period in the eastern margin of the Ordos Basin, China, was formed in a marine-continental facies sedimentary environment. With a high content of total organic carbon (TOC) and a large cumulative thickness, it is considered a good source rock for shale gas development. The sedimentary environment of marine-continental transitional shale is obviously different from that of marine shale, which leads to different enrichment characteristics of organic matter. In this paper, shale samples were collected from $\mathrm{XX}^{\#}$ well of the Taiyuan and Shanxi Formations across the Upper Carboniferous-Lower Permian, which is typical marine-continental transitional shale. The TOC, major elements, and trace elements were measured, and the formation and preservation conditions were investigated using multiple geochemical proxies, including paleoclimate, redox parameters, paleoproductivity, and controls on the accumulation of organic matter. The TOC of Shanxi Formation is higher than that of Taiyuan Formation. In the Taiyuan Formation, TOC is positively related to the redox index $(\mathrm{V}, \mathrm{U}$, and $\mathrm{V} / \mathrm{Cr})$, indicating that the dysoxic bottom water environment is the key factor controlling organic matter accumulation. For Shanxi Formation, there is a positive correlation between TOC and paleoclimate, which indicates that the enrichment of organic matter is affected by warm and humid paleoclimate and oxic environment. In addition, the paleoproductivity is lower with a positive correlation with TOC for the marine-continental transitional organicrich shale, suggesting that it was inferior to the gathering of organic matter.

\section{Introduction}

The remarkable success of shale gas development in North America has led to the vigorous development of shale gas exploration and increased the investigation of global shale gas potential [1-6]. To increase domestic energy supply through shale gas development, the Chinese government has made ambitious plans. Geological survey and exploration activities are being carried out all over the country [7]. So far, China has developed several shale gas fields in Sichuan Basin.
According to the sedimentary environment, China's organic rich shale can be divided into three types: marine shale, marine-continental transitional shale, and continental shale $[5,8]$. To date, China has conducted a series of marine, marine-continental transitional, and continental shale gas tests. The industry and academia have always been interested in marine shale rich in quartzite and compared it with the successful marine shale in the United States, while terrigenous and transitional shale, due to their clay-rich nature, is generally considered to be less promising $[9,10]$. However, 
organic-rich shales in the marine-continental transitional facies are mainly black coal-bearing shales with high total organic carbon (TOC) content and large accumulated thickness, which are the best characteristics and quality for developing shale gas [11]. The Carboniferous-Permian is a key period for the change of sedimentary environment from marine to continental facies in China. Shales rich in marine-continental transitional organic matter are widely deposited, including Northern China, the Tarim Basin and the Junggar Basin of the Carboniferous-Permian, the Middle Carboniferous Benxi Formation, the Upper Carboniferous Taiyuan Formation, and the Lower Permian Shanxi Formation in the Ordos Basin $[12,13]$. Although extensive research has been conducted on the characteristics of transitional shale gas reservoirs $[9,14-16]$, the role of sedimentary environments in controlling transitional shale development and reservoir characteristics is poorly understood. As noted previously [17-20], the sedimentary environment largely controls the shale thickness, distribution, and geochemical and petrophysical characteristics. Therefore, in order to better understand the potential of transitional shale gas, it is necessary to further study the reservoir characteristics and their relationship with sedimentary environment.

The Ordos Basin, located in the western margin of the North China platform, is an important petroliferous basin in China $[21,22]$. In the Late Paleozoic, the continental margin basin was dominated by marine sedimentation, the coastal lake basin by marine-continental transitional sedimentation, and the inland depression lake basin by continental clastic sedimentation. During the sedimentary environment evaluation, multiple sets of shales were deposited [10, 21-23]. Organic matter-rich shales in the basin are mainly distributed in the Benxi Formation (Middle Carboniferous), Taiyuan Formation (Upper Carboniferous), and Shanxi Formation (Lower Permian) [24]. In this paper, the main elements, trace elements, and TOC of the organicrich shale of Taiyuan and Shanxi Formations in the eastern margin of Ordos Basin in China are tested. The dynamic response of organic matter enrichment to paleoclimate, redox conditions, paleoproductivity, and debris flow was established. Finally, the key factors affecting the enrichment of organic-rich shale during the marine-continental transitional period are discussed. The results of this study can provide a basis for further understanding of shale gas potential in coal measures and could guide shale gas exploration in other transitional basins.

\section{Geological Background}

The Ordos Basin located in the north of central China (Figure 1(a)) is the second largest sedimentary basin in China, with an area of about $37 \times 10^{4} \mathrm{~km}^{2}$. The oil content of the Mesozoic reservoir in Ordos Basin is up to $10 \times 10^{8}$ $\mathrm{m}^{3}$ [25], and natural gas reserves up to $1789.3 \times 10^{9} \mathrm{~m}^{3}$ [26]. There are mainly six substructures in the basin: Jinxi fold belt in the east, Tianhuan depression and western margin thrust belt in the west, Weibei uplift in the south, Yimeng uplift in the north, and Yishan slope in the center (Figure 1(a)) [25]. The Ordos Basin has experienced four stages of evolution: Early Paleozoic shallow sea platform, Late Paleozoic offshore plain, Mesozoic intercontinental basin, and Cenozoic fault depression [27]. The long-lived polycyclic Ordos Basin formed from the Middle Proterozoic to the Tertiary; Paleozoic, Mesozoic, and Cenozoic sedimentary strata were developed and preserved in the basin (Figure 1(b)) $[27,28]$. Especially in the Paleozoic offshore plain stage, the Ordos Basin developed a series of marine-terrestrial transitional strata. These strata are characterized by lithologic assemblages consisting of bedded shale, tight sand, and coal seams [29, 30].

From the Middle Proterozoic to the Early Paleozoic in Ordos Basin, thousands of meters thick carbonate rocks were deposited [31]. Under the influence of the Caledonian movement, the Ordos Basin was in the uplift period from Middle Ordovician to Middle Carboniferous, which led to the denudation of the strata from the Late Ordovician to Early Carboniferous. In the Late Carboniferous, tectonic subsidence occurred again in the Ordos Basin, accompanied by transgression. Subsequently, regressions occurred from the last stage of the Late Carboniferous to the beginning of the Permian [32]. During the Permian periods, the Ordos Basin was dominated by fluvial-lake sedimentary environment. Overall, the Upper Paleozoic in Ordos Basin was deposited in the transitional environment of marine-continental facies, and the Lower Permian Shanxi Formation is one of the above coal-bearing strata. It is widely distributed in the southeast of Ordos Basin, with medium burial depth (generally between 2000 and 3500 meters) and large thickness (90-110 meters). The Lower Permian Shanxi Formation was deposited in the transition stage from transitional environment to continental environment and features delta front-coastal marsh sediments, thin-bedded sandstone and the roof of the No. 3 coal seam which is usually mudstone or sandstone, and two to four sets of black shale with a thickness of from 40 to $135 \mathrm{~m}$ [30]. The Taiyuan Formation is composed of black shale, coal, limestone, and sandstone, which are deposited in delta plain and tidal flat lagoon environment [30], and the roof of the No. 8 coal seam is generally limestone.

\section{Samples and Methods}

Samples were taken from cored well $\mathrm{XX}^{\#}$ located in the eastern margin of Ordos Basin, China (Figure 1(a)). The lithology of the core samples included gray thinly bedded fine sandstone, coal, argillaceous siltstone, and thick black shale (Figure 1(b)). A total of 23 samples were chosen at relatively regular intervals from a depth of 1508.6 to $1568.6 \mathrm{~m}$. To minimize the potential effects of surface weathering and contamination from sample collection and storage, all of the investigated samples used for analyses were freshly cut after removing the weathered surface of the core and then pulverized to powders.

Fresh samples were ground in an agate mortar to a particle size of less than 200 mesh and then divided into several parts for total organic carbon content (TOC), $\delta^{13} \mathrm{C}_{\text {org }}$, and major and trace element geochemical analyses. For TOC measurements, sample powders were soaked in $4 \mathrm{M}$ hydrochloric acid solution for $24 \mathrm{~h}$ to remove carbonate, then 


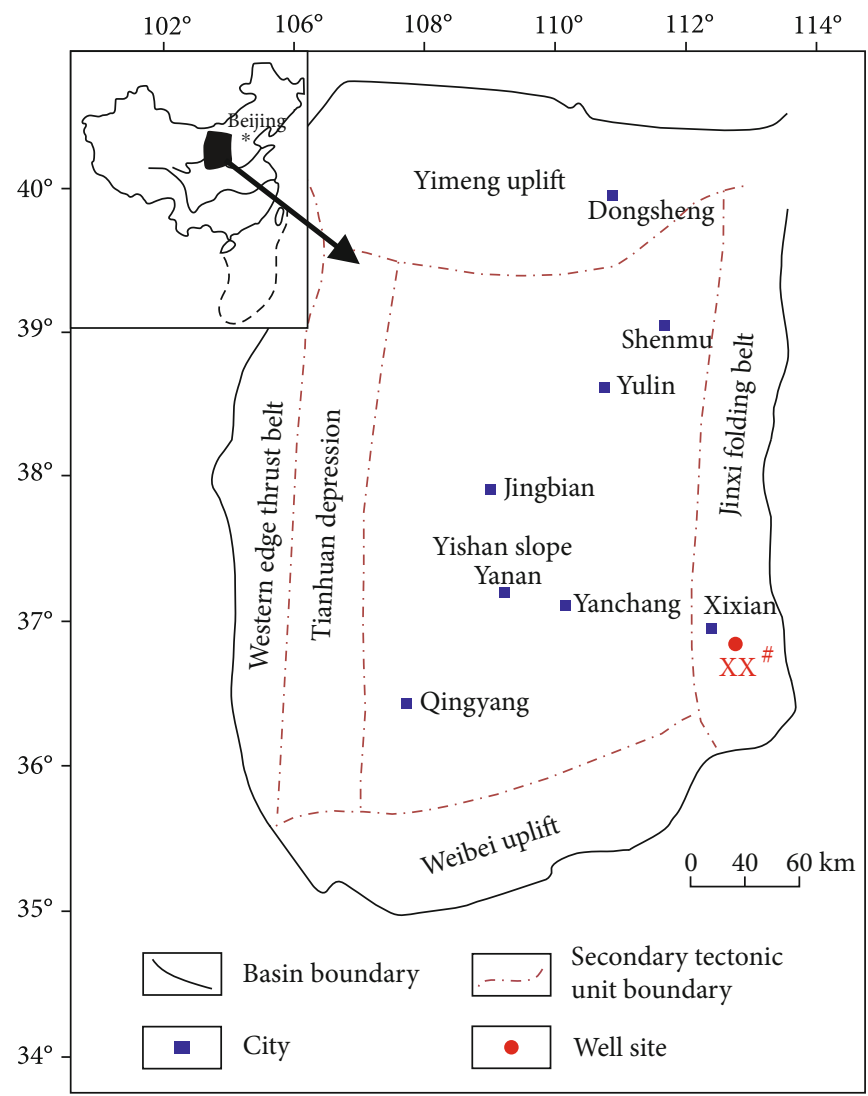

(a)

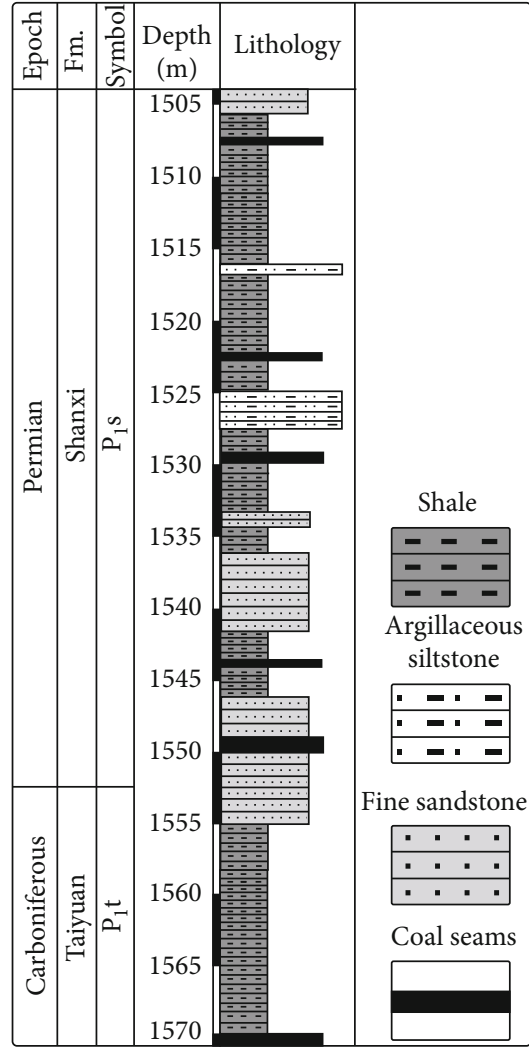

(b)

Figure 1: (a) Location of the study area and the substructure zones of the Ordos Basin (modified from Duan et al. [25]). (b) Petrological characterization of the drilled section of $\mathrm{XX}^{\#}$ well that corresponds to the cored section samples in this study.

washed to neutrality with deionized water and dried overnight $\left(50^{\circ} \mathrm{C}\right)$. Finally, the samples are analyzed by a carbonsulfur analyzer LECO CS-400 to determine carbon and sulfur. The analysis accuracy for TOC and TS is higher than $1 \%$. The decalcified samples for $\delta^{13} \mathrm{C}_{\text {org }}$ analysis were burned into $\mathrm{CO}_{2}$ gas by the combustion method, and then, $\mathrm{CO}_{2}$ gas was purified and collected by a liquid nitrogen cold trap. Afterwards, carbon isotopic ratios were analyzed on the Finnigan MAT-253 mass spectrometer and reported in per mille via the Vienna PDB standard. The analysis accuracy for $\delta^{13} \mathrm{C}_{\text {org }}$ is higher than $\pm 0.06 \%$. Chemical analyses of major elements were carried out by an X-ray fluorescence spectrometer (XRF), using fused glass discs prepared with 1:10 proportion of samples: flux. Trace element concentrations were measured by a VG PQ2 Turbo inductively coupled plasma source mass spectrometer (ICP-MS), as described by Yan et al. [33], The precisions are better than 3\% for major elements and $4 \%$ for trace elements.

\section{Results}

Vertical variations of organic carbon contents, $\delta^{13} \mathrm{C}_{\text {org }}$, major and trace element concentrations, and calculated $\mathrm{CIA}, \mathrm{Rb} / \mathrm{Sr}$, $\mathrm{Cu} / \mathrm{Zn}, \mathrm{Th} / \mathrm{U}, \mathrm{V} / \mathrm{Cr}$, and $\mathrm{Sr} / \mathrm{Ba}$ ratios of the $\mathrm{XX}^{\#}$ well are presented in Figures 2 and 3. All the analysis data are also listed in Tables 1 and 2.
Table 1 shows the TOC content and $\delta^{13} \mathrm{C}_{\text {org }}$ value of the marine-continental transitional samples. TOC value of the transitional shale is between $1.2 \%$ and $12.4 \%$, with an average of $5.2 \%$. The organic carbon isotopes are mainly controlled by organic matter sources, which are stable in the thermal evolution of geological history, and are generally used to evaluate the types of organic matter in overmature shale. The $\delta^{13} \mathrm{C}_{\text {org }}$ values of the samples are between $-26.5 \%$ and $-23.0 \%$, indicating that the transition shale organic matter is mainly type III kerogen.

The main element analysis results are shown in Table 1. Among the marine-continental transitional samples, $\mathrm{SiO}_{2}$ (35.01-60.27\%) and $\mathrm{Al}_{2} \mathrm{O}_{3}(10.38-27.81 \%)$ are the most abundant oxides. The second abundant oxides are $\mathrm{Fe}_{2} \mathrm{O}_{3}$ (6.26-13.57\%), $\mathrm{MgO}$ (1.02-14.22\%), $\mathrm{K}_{2} \mathrm{O}$ (1.05-8.62\%), $\mathrm{Na}_{2} \mathrm{O}(1.05-6.91 \%)$, and $\mathrm{CaO}(0.59-3.97 \%)$. The content of other oxides, including $\mathrm{MnO}, \mathrm{TiO}_{2}$, and $\mathrm{P}_{2} \mathrm{O}_{5}$, was lower than $1.00 \%$. When compared with the PAAS (post-Archean Australian shale) values [34], the $\mathrm{Fe}_{2} \mathrm{O}_{3}$ (average 10.19\%) and $\mathrm{K}_{2} \mathrm{O}$ (average $3.93 \%$ ) content of the marine-continental transitional samples is slightly higher than that of the PAAS. In addition, the content of $\mathrm{Al}_{2} \mathrm{O}_{3}$ (avg. 18.41\%) and $\mathrm{SiO}_{2}$ (avg. 48.87\%) is relatively lower than that of the PAAS. Compared to PAAS, $\mathrm{MnO}$ and $\mathrm{TiO}_{2}$ in the shale are slightly depleted.

Trace elements are systematically enriched across the marine-continental transitional samples (Table 2). The 

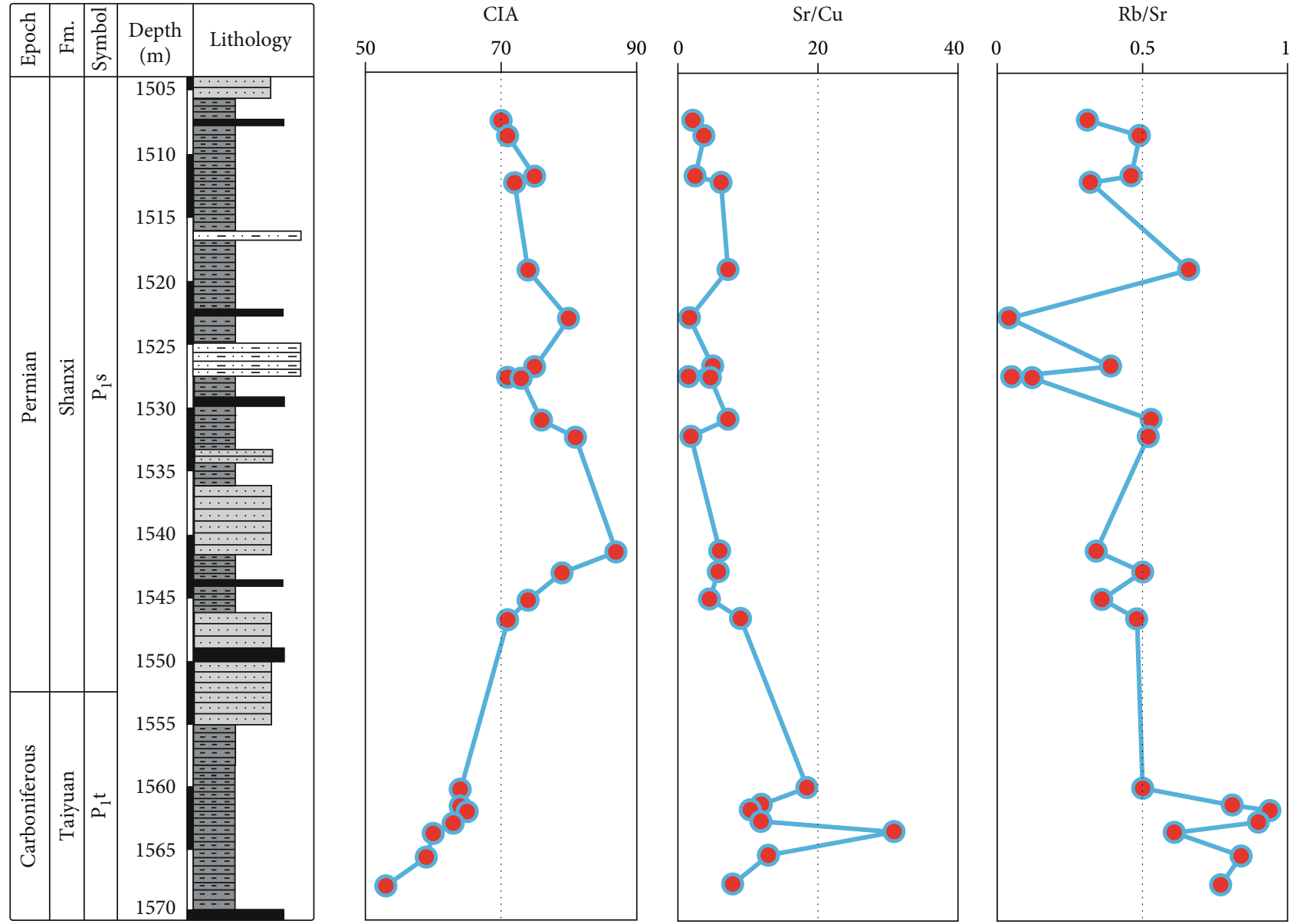

FIgURE 2: The stratigraphic distribution of paleoclimate proxies of the studied samples.

contents of $\mathrm{Ba}, \mathrm{Zr}$, and $\mathrm{Sr}$ are relatively high, with the average contents of 394.7, 325.7, and $165.0 \mathrm{ppm}$, respectively, while the average contents of $\mathrm{Sc}, \mathrm{V}, \mathrm{Cr}, \mathrm{Ni}, \mathrm{Cu}, \mathrm{Zn}, \mathrm{Rb}, \mathrm{Th}$, and $\mathrm{U}$ are $14.8,99.3,52.5,34.9,28.1,115.0,84.4,17.6$, and $5.6 \mathrm{ppm}$, respectively, exhibiting large variations in magnitude.

\section{Discussion}

5.1. Paleoclimate Proxies. The paleoclimate affected the chemical weathering intensity of the sediment and the debris flow in the source area and finally determined the mineral composition and chemical composition of the sediment. The chemical index of alteration (CIA) can be used to assess the intensity of chemical weathering and to describe climate change [35-39]. When the climate is cold and dry, the CIA value is between 50 and 70, indicating that the degree of chemical weathering is low, while in the warm and humid climate, the CIA value is between 70 and 85 , indicating that the degree of chemical weathering is medium. When the CIA exceeds 85 , the value indicates highly chemical weathering associated with hot and humid climates [40]. According to the difference of principal components, the marinecontinental transitional samples can be divided into two groups (Table 1, Figure 2). The first group is the distribution area of Taiyuan Formation samples with relatively low data points, while the second group is the main distribution area of Shanxi Formation samples with relatively high data points. The CIA value of Shanxi Formation is generally between 70 and 87 (mean 75); however, the CIA value of Taiyuan Formation decreased significantly, fluctuating between 53 and 68 (average 62). Therefore, the CIA values indicate that the paleoclimate change in the Early Carboniferous and Late Permian can be divided into two stages: from cold and dry to warm and humid. In addition, the CIA of Shanxi Formation is positively correlated with TOC $\left(R^{2}=0.44\right.$, Figure 4$)$, which indicates that climate has a great impact on total organic carbon and that warm and humid climate is conducive to the growth of the advanced plants. Because of the strong chemical weathering, the river mixed the terrigenous clastic and plant clastic into the sedimentary water, providing rich organic matter for the delta sedimentary system that was close to the source rock. The average CIA value of the Taiyuan Formation was slightly lower than that of the Shanxi Formation. Although the climate of Taiyuan is similar to that of Shanxi, the correlation with TOC is weak $\left(R^{2}=0.10\right.$, Figure 4). This shows that the sedimentary environment of the lagoon tidal flat of Taiyuan Formation is far away from 

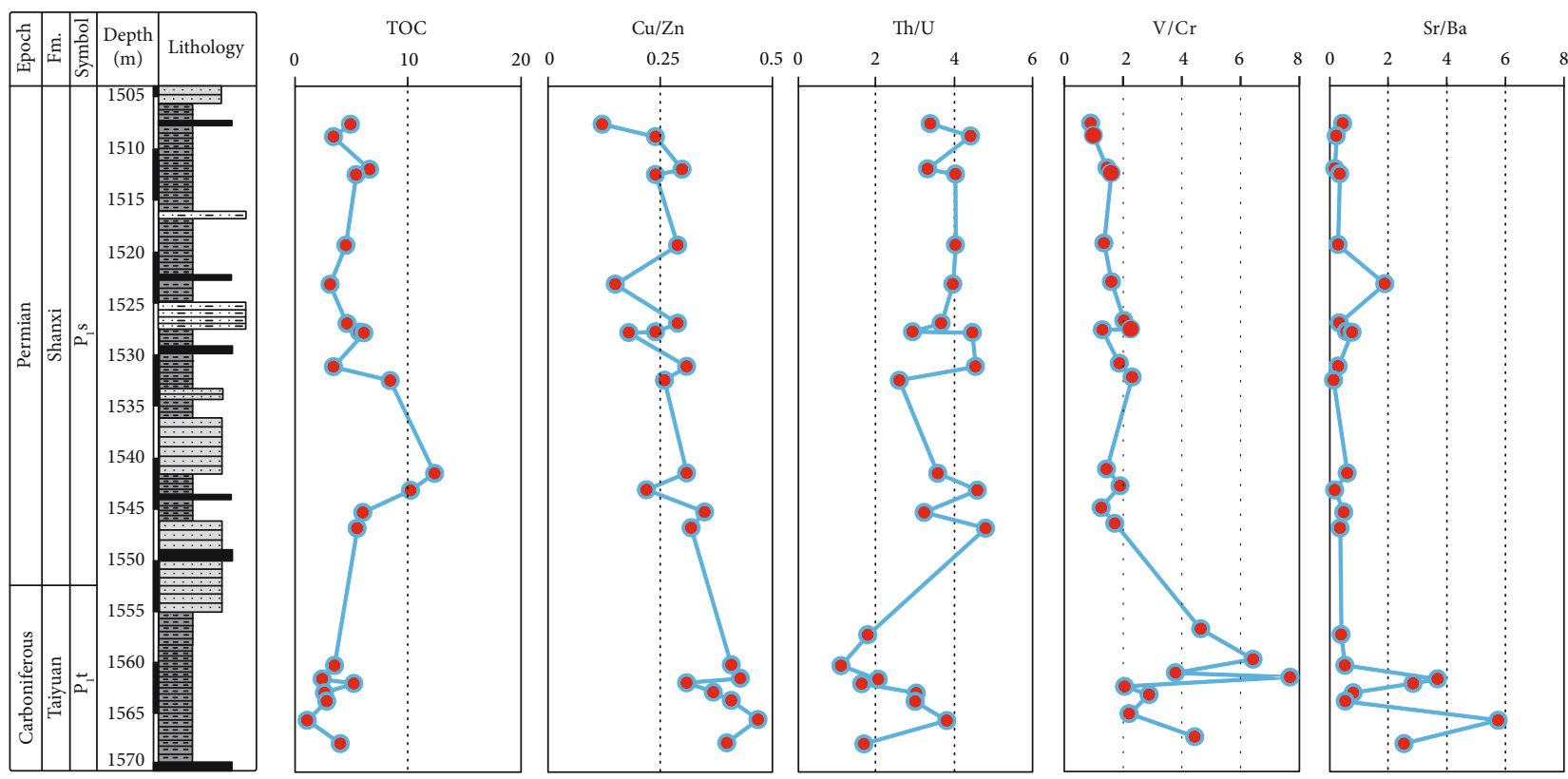

Figure 3: The stratigraphic distribution of TOC, redox proxies $(\mathrm{Cu} / \mathrm{Zn}, \mathrm{Th} / \mathrm{U}$, and $\mathrm{V} / \mathrm{Cr})$, and paleosalinity proxies $(\mathrm{Sr} / \mathrm{Ba})$ of the studied samples.

the source area and greatly influenced by the ocean. Therefore, the control of climate on organic matter concentration is weakened.

When the climate is warm and humid, $\mathrm{Fe}, \mathrm{V}, \mathrm{Ni}, \mathrm{Ba}, \mathrm{Co}$, and other elements are dissolved in large quantities [41, 42]. When the climatic conditions change from warm to dry, the evaporation of water gradually increases, and the elements are precipitated in the form of salts, resulting in a relatively high content of these elements in sedimentary rocks [43]. The change of the concentration of these elements is very sensitive to the change of paleoclimate, and the change of their content and ratio can be used to analyze the change of paleoclimate [44]. The trace elements $\mathrm{Cu}, \mathrm{Sr}$, and $\mathrm{Rb}$ and their ratios $(\mathrm{Sr} / \mathrm{Cu}, \mathrm{Rb} / \mathrm{Sr})$ are very sensitive to different pale environmental conditions and can be used to analyze the sedimentary environment in specific periods [45-48].

The $\mathrm{Sr} / \mathrm{Cu}$ ratio indicates a humid and warm climate when it falls within the range 1-10, and a dry, hot climate when it is greater than 10 [45-48]. The ratio of $\mathrm{Sr} / \mathrm{Cu}$ in Shanxi Formation was mainly between 1.6 and 9.0, indicating that the paleoclimate was mainly wet and warm. In the Taiyuan Formation, the $\mathrm{Sr} / \mathrm{Cu}$ ratio gradually increased (from 7.9 to 30.9). Therefore, during the transition from the Taiyuan Formation to the Shanxi Formation, the $\mathrm{Sr} / \mathrm{Cu}$ ratio showed a decreasing trend with the transition from the paleoenvironment to the humid and warm climate (Table 2, Figure 2). When the $\mathrm{Rb} / \mathrm{Sr}$ ratio is high, it indicates that the paleoenvironment hydrodynamic conditions are weak at that time; when the ratio is low, it means that the rainfall is large and the hydrodynamic conditions are strong [46-48]. The $\mathrm{Rb} / \mathrm{Sr}$ ratio in the study area is generally between 0.04 and 0.94 . Combined with the values in Figure 2, it can be seen that from the Taiyuan Formation to the Shanxi Formation, the $\mathrm{Rb} / \mathrm{Sr}$ ratio gradually decreased and the precipitation increased, indicating that the paleoenvironment became humid. In general, the climate in the study area is mainly warm and humid. From Taiyuan Formation to Shanxi Formation, the paleoenvironment changed to humid environment.

5.2. Redox Conditions. The occurrence and enrichment of $\mathrm{Ni}$, $\mathrm{Co}, \mathrm{U}, \mathrm{Th}, \mathrm{V}, \mathrm{Cr}, \mathrm{Cu}, \mathrm{Zn}$, and other trace elements in sedimentary rocks are different under different redox conditions [49]. In different environments, the sensitivity of different trace elements to redox is also very different [50]. Some trace elements are easily to be dissolved under oxic conditions but are stable under anoxic conditions and precipitate out being enriched in sedimentary deposits [51]. Therefore, the contents of trace elements and their corresponding ratios can be used to analyze the changes of redox conditions in sedimentary environment [49].

Combined with the content of $\mathrm{Ni}, \mathrm{Co}, \mathrm{U}, \mathrm{Th}, \mathrm{V}, \mathrm{Cr}, \mathrm{Cu}$, $\mathrm{Zn}$, and other elements, it can be based on $\mathrm{V} / \mathrm{Cr}, \mathrm{Ni} / \mathrm{Co}$, $\mathrm{U} / \mathrm{Th}, \delta \mathrm{U}(6 \mathrm{U} /(3 \mathrm{U}+\mathrm{Th})), \mathrm{V} /(\mathrm{V}+\mathrm{Ni}), \mathrm{Cu} / \mathrm{Zn}$, and other element ratios to characterize changes in the redox state of the deposition environment [38, 49-54]. These trends indicate the preservation conditions of organic matter in sediments (Table 2). The $\mathrm{V} /(\mathrm{V}+\mathrm{Ni}$ ) values can reflect the redox conditions and sedimentary water stratification characteristics of the sedimentary area at a specific period [55, 56]. When $\mathrm{V} /(\mathrm{V}+\mathrm{Ni})<0.46$, the water environment is rich in oxygen. When $0.46<\mathrm{V} /(\mathrm{V}+\mathrm{Ni})<0.60$, the water environment was hypoxic and the water stratification was weak. When $0.54<\mathrm{V} /(\mathrm{V}+\mathrm{Ni})<0.80$, the water is in an anaerobic environment, and the water is moderately stratified. When $\mathrm{V} /(\mathrm{V}+\mathrm{Ni})>0.84$, the water body was stratified and strongly reduced $[52,55-57]$. In general, the higher the $\mathrm{V} /(\mathrm{V}+\mathrm{Ni})$ value, the higher the degree of water reduction and 
TABLE 1: Concentrations and/or isotopic compositions of TOC, $\delta^{13} \mathrm{C}_{\text {org }}$, major elements and the calculated element ratios, and CIA of sediments from the Upper Carboniferous and Lower Permian at $\mathrm{XX}^{\#}$ well.

\begin{tabular}{|c|c|c|c|c|c|c|c|c|c|c|c|c|c|c|c|c|}
\hline Sample & Strata/Fm. & Depth $(\mathrm{m})$ & TOC & $\delta^{13} \mathrm{C}_{\text {org }}$ & $\mathrm{SiO}_{2}$ & $\mathrm{Al}_{2} \mathrm{O}_{3}$ & $\mathrm{CaO}$ & $\mathrm{K}_{2} \mathrm{O}$ & $\mathrm{Na}_{2} \mathrm{O}$ & $\mathrm{Fe}_{2} \mathrm{O}_{3}$ & $\mathrm{MgO}$ & $\mathrm{MnO}$ & $\mathrm{TiO}_{2}$ & $\mathrm{P}_{2} \mathrm{O}_{5}$ & CIA & $\mathrm{P} / \mathrm{Ti}$ \\
\hline $\mathrm{XX}-1$ & \multirow{15}{*}{ Shanxi } & 1508.6 & 5.0 & -24.1 & 53.65 & 22.75 & 0.63 & 4.34 & 5.07 & 9.08 & 1.03 & 0.77 & 0.53 & 0.15 & 70 & 0.10 \\
\hline$X X-2$ & & 1509.8 & 3.5 & -23.9 & 38.06 & 25.45 & 0.59 & 3.12 & 6.91 & 10.34 & 10.21 & 0.32 & 0.16 & 0.08 & 71 & 0.18 \\
\hline XX-3 & & 1512.9 & 6.7 & -24.7 & 49.32 & 16.32 & 2.81 & 2.27 & 1.05 & 11.23 & 7.32 & 0.16 & 0.31 & 0.21 & 75 & 0.24 \\
\hline $\mathrm{XX}-4$ & & 1513.4 & 5.5 & -26.5 & 50.21 & 20.53 & 2.07 & 2.92 & 3.79 & 8.56 & 6.53 & 0.51 & 0.73 & 0.24 & 72 & 0.12 \\
\hline$X X-5$ & & 1520.1 & 4.6 & -24.5 & 35.35 & 24.22 & 1.55 & 4.63 & 2.54 & 13.33 & 14.22 & 0.34 & 0.28 & 0.12 & 74 & 0.15 \\
\hline XX-6 & & 1523.8 & 3.2 & -23.4 & 56.23 & 16.17 & 1.01 & 1.05 & 2.83 & 12.45 & 1.17 & 0.25 & 0.36 & 0.24 & 80 & 0.24 \\
\hline XX-7 & & 1527.5 & 4.7 & -24.2 & 38.22 & 22.62 & 1.05 & 3.45 & 3.69 & 10.02 & 12.62 & 0.38 & 0.49 & 0.19 & 75 & 0.14 \\
\hline XX-8 & & 1528.3 & 5.8 & -23.5 & 40.21 & 25.51 & 0.63 & 5.26 & 5.06 & 10.68 & 5.51 & 0.78 & 0.67 & 0.16 & 71 & 0.09 \\
\hline XX-9 & & 1528.4 & 6.2 & -25.3 & 55.23 & 15.07 & 0.76 & 1.38 & 4.03 & 9.09 & 8.07 & 0.45 & 0.63 & 0.21 & 73 & 0.12 \\
\hline $\mathrm{XX}-10$ & & 1531.6 & 3.5 & -23.1 & 50.23 & 13.53 & 1.05 & 2.31 & 1.67 & 11.53 & 13.53 & 0.09 & 0.33 & 0.22 & 76 & 0.24 \\
\hline $\mathrm{XX}-11$ & & 1532.9 & 8.5 & -24.1 & 57.38 & 14.19 & 0.99 & 1.21 & 2.02 & 8.23 & 9.19 & 0.12 & 0.48 & 0.25 & 81 & 0.19 \\
\hline $\mathrm{XX}-12$ & & 1541.7 & 12.4 & -23.5 & 35.01 & 16.34 & 1.27 & 1.06 & 1.11 & 10.31 & 13.34 & 0.23 & 0.26 & 0.33 & 87 & 0.46 \\
\hline XX-13 & & 1543.3 & 10.3 & -23.9 & 35.35 & 27.81 & 1.17 & 3.98 & 2.81 & 9.55 & 11.81 & 0.56 & 0.27 & 0.18 & 79 & 0.24 \\
\hline XX-14 & & 1545.4 & 6.1 & -24.3 & 45.43 & 25.56 & 3.97 & 3.69 & 2.52 & 6.26 & 7.05 & 0.75 & 1.31 & 0.39 & 74 & 0.11 \\
\hline XX-15 & & 1546.9 & 5.6 & -23.3 & 39.03 & 22.28 & 3.27 & 5.26 & 1.13 & 10.49 & 12.28 & 0.98 & 0.43 & 0.18 & 71 & 0.15 \\
\hline$X X-16$ & \multirow{8}{*}{ Taiyuan } & 1557.0 & 4.9 & -23.8 & 60.26 & 16.71 & 1.57 & 5.33 & 1.15 & 9.85 & 1.71 & 0.07 & 0.63 & 0.09 & 68 & 0.05 \\
\hline XX-17 & & 1559.9 & 3.6 & -24.0 & 52.26 & 16.25 & 0.65 & 7.64 & 1.16 & 9.66 & 6.25 & 0.76 & 0.51 & 0.15 & 64 & 0.11 \\
\hline XX-18 & & 1561.2 & 2.5 & -23.0 & 55.21 & 13.82 & 0.68 & 2.31 & 5.19 & 11.25 & 1.02 & 0.27 & 0.73 & 0.14 & 64 & 0.07 \\
\hline XX-19 & & 1561.6 & 5.3 & -23.6 & 60.23 & 10.38 & 1.02 & 1.21 & 3.96 & 12.56 & 1.38 & 0.01 & 0.22 & 0.16 & 65 & 0.26 \\
\hline$X X-20$ & & 1562.5 & 2.7 & -23.7 & 54.55 & 14.78 & 1.55 & 6.68 & 1.52 & 8.17 & 7.78 & 0.95 & 0.85 & 0.31 & 63 & 0.13 \\
\hline XX-21 & & 1563.3 & 2.9 & -24.3 & 51.89 & 16.25 & 0.65 & 7.64 & 3.16 & 9.43 & 6.25 & 0.01 & 0.51 & 0.19 & 60 & 0.13 \\
\hline$X X-22$ & & 1565.1 & 1.2 & -24.6 & 60.27 & 11.75 & 0.63 & 5.09 & 3.07 & 13.57 & 1.75 & 0.25 & 0.54 & 0.18 & 59 & 0.12 \\
\hline $\mathrm{XX}-23$ & & 1567.3 & 4.1 & -25.6 & 50.35 & 15.09 & 0.74 & 8.62 & 4.02 & 8.65 & 8.09 & 0.04 & 0.61 & 0.07 & 53 & 0.04 \\
\hline Average & & & 5.2 & -24.1 & 48.87 & 18.41 & 1.32 & 3.93 & 3.02 & 10.19 & 7.31 & 0.39 & 0.51 & 0.19 & 71 & 0.16 \\
\hline
\end{tabular}

delamination during the deposition process $[52,56,57]$. The $\mathrm{V} /(\mathrm{V}+\mathrm{Ni})$ value of the shale samples in the study area is $0.44 \sim 1.00$ (avg. 0.77), indicating that the paleoenvironment in the sedimentary period was moderately stratified and the seawater cycle was relatively stable. The higher the $\mathrm{Cu} / \mathrm{Zn}$ value, the lower the oxygen content in the water environment and the higher the degree of reduction $[58,59]$. From Taiyuan Formation to Shanxi Formation, the $\mathrm{Cu} / \mathrm{Zn}$ ratio gradually decreased (Figure 3), which also indicates that the reduction degree is decreasing upward.

The $\mathrm{Th} / \mathrm{U}$ and $\mathrm{V} / \mathrm{Cr}$ ratios can also be used to estimate the degree of bottom water oxygenation during sedimentation [19, 60-62]. In sedimentary environments, Th mainly exists in the form of insoluble $\mathrm{Th}^{4+}$. For $\mathrm{U}$, it appears in the form of soluble $\mathrm{U}^{6+}$ in the oxidized environment, leading to the loss of $U$ in the sediments. Therefore, the high $\mathrm{Th} / \mathrm{U}$ ratio usually means strong oxidation conditions. When the Th/U ratio is less than 2 , it indicates that it is in an anoxic environment. As the oxygen content increases, it can reach to 8 [61, 62]. The Th/U ratio of Taiyuan Formation is 1.1-3.8 (average 2.3), and that of Shanxi Formation is 2.6-4.8 (average 3.8) (Table 2, Figure 3), indicating that the sedimentary environment of Taiyuan Formation is a dysoxic-oxic sedimentary environment, and the oxygen content of water is lower than that of Shanxi Formation. The V/Cr ratio increases with the decrease of oxygen content, and the high $\mathrm{V} / \mathrm{Cr}$ reflects anoxic conditions. The $\mathrm{V} / \mathrm{Cr}$ ratio in oxic environment is low, generally less than 2. When it ranges from 2 to 4.25 , it indicates that it is in a dysoxic environment. For the suboxic to anoxic environment, the ratio of $\mathrm{V} / \mathrm{Cr}$ exceeds 4.25 [49]. The ratio of $\mathrm{V} / \mathrm{Cr}$ in Taiyuan Formation ranged from 2.1 to 7.7 (average 4.3 ), which mainly indicated suboxic to anoxic conditions. As for Shanxi Formation, the ratio of $\mathrm{V} / \mathrm{Cr}$ varies from 0.9 to 2.3 (average 1.6), indicating that it is mainly oxic conditions (Table 2, Figure 3). Combined with the ratios of $\mathrm{Th} / \mathrm{U}$ and $\mathrm{V} / \mathrm{Cr}$, the marine-continental transitional samples were deposited in a dysoxic environment, while the samples for the Shanxi Formation were deposited in a relatively oxic environment.

In Taiyuan Formation, TOC was negatively correlated with $\mathrm{Th} / \mathrm{U}\left(R^{2}=0.59\right.$, Figure 5$)$, while TOC was positively correlated with $\mathrm{U}, \mathrm{V}$, and $\mathrm{V} / \mathrm{Cr}\left(R^{2}=0.65,0.87\right.$, and 0.62 , Figure 5, respectively), indicating that the dysoxic environment of the bottom water with drawdown oxygen content favors the accumulation of TOC. For the Shanxi Formation, there was no weak negative correlation between TOC and $\mathrm{U}, \mathrm{Th} / \mathrm{U}, \mathrm{V}$, and $\mathrm{V} / \mathrm{Cr}$ (Figure 5). This means that the redox condition has little influence on the enrichment of TOC under the oxic environment with the increasing content of oxygen. 


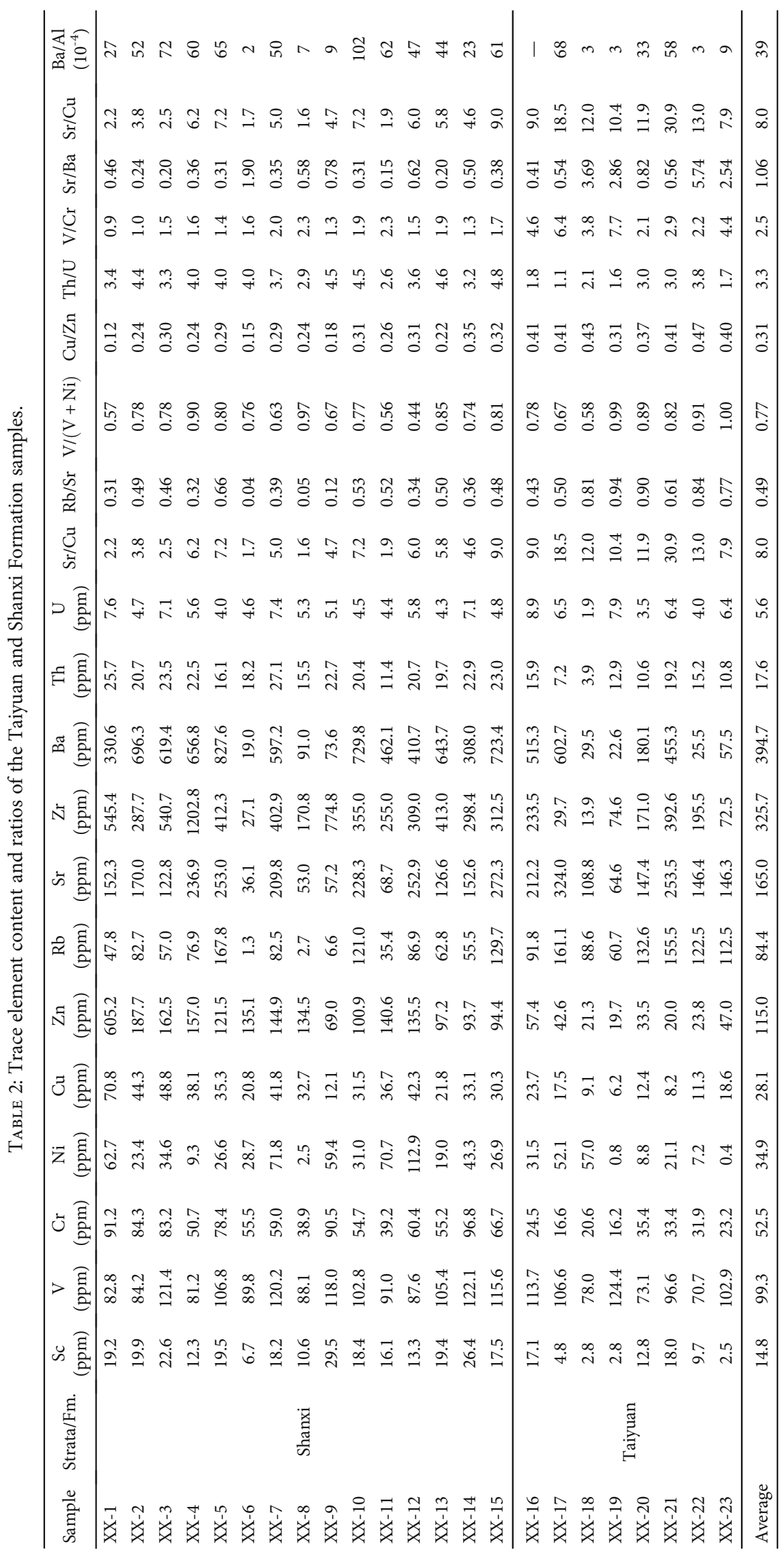




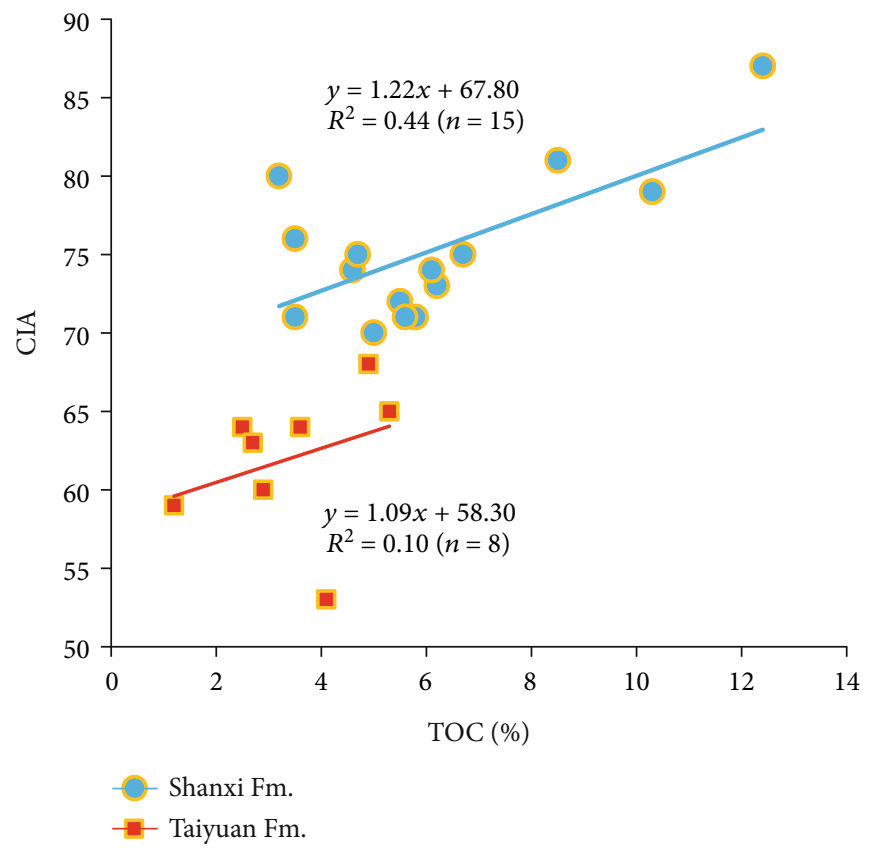

FIgURE 4: Crossplots of TOC content versus CIA of the samples in the Taiyuan and Shanxi Formations.

5.3. Paleosalinity. Paleosalinity is the water salt in the sediments of a specific period in ancient times. It is an important symbol to distinguish marine facies, marine-continental transitional environment, and continental sedimentary environment $[55,63]$. The processing and analysis of paleosalinerelated trace element data is an important means to reveal the characteristics of paleoenvironment and paleoclimate. Common methods for calculating paleosalinity include the element ratio method, trace element method, and isotope method, with the element ratio method adopted here [63, 64]. The barium $\left(\mathrm{Ba}^{2+}\right)$ compounds have lower solubility than strontium $\left(\mathrm{Sr}^{2+}\right)$ compounds, so $\mathrm{Ba}^{2+}$ is more likely to react with $\mathrm{SO}_{4}{ }^{2-}$ to form a precipitate than $\mathrm{Sr}^{2+}$. As the salinity of lake/seawater increases, the concentration of $\mathrm{SO}_{4}{ }^{2-}$ increases and $\mathrm{Ba}^{2+}$ is first precipitated in the form of $\mathrm{BaSO}_{4}$, while $\mathrm{Sr}^{2+}$ is precipitated in the form of $\mathrm{SrSO}_{4}$ only when the concentration of lake/seawater reaches the critical value [63, 64]. The low salinity sediments formed in the early stage of sedimentary environment are characterized by $\mathrm{Ba}^{2+}$ enrichment and $\mathrm{Sr}^{2+}$ deficiency, and vice versa. Therefore, $\mathrm{Sr} / \mathrm{Ba}$ is a common indicator of ancient salinity, indicating the relative strength of evaporation, which is the relative height of the sedimentary environment. The higher the ratio of $\mathrm{Sr} / \mathrm{Ba}$, the higher the paleosalinity of the sedimentary environment; and the lower the ratio, the lower the paleosalinity of the sedimentary environment [65-70]. The criteria for classification according to the $\mathrm{Sr} / \mathrm{Ba}$ ratio in the study area are the following: when $\mathrm{Sr} / \mathrm{Ba}>1$, the sedimentary environment is marine sediment; transitional sedimentation is when $0.5<\mathrm{Sr} / \mathrm{Ba}<1$, and terrestrial sedimentation is when $\mathrm{Sr} / \mathrm{Ba}<0.5$ [70].

According to Table 2, the Sr/Ba range of the Taiyuan Formation is $0.41-5.74$, with an average value of 2.14, so it can be classified as mainly composed of marine and marinecontinental transitional sediments. The $\mathrm{Sr} / \mathrm{Ba}$ ratio of Shanxi Formation is $0.15-1.90$, with an average of 0.49 , which belongs to continental sedimentation. During the transition from the Taiyuan Formation to the Shanxi Formation, the $\mathrm{Sr} / \mathrm{Ba}$ ratio decreased significantly near the stratigraphic boundary (Figure 3), indicating that a strong transgression occurred in the late Taiyuan Formation. The range of $\mathrm{Sr} / \mathrm{Ba}$ values in Taiyuan Formation samples is relatively wide, which indicates that the transgression and regression processes are frequent in this area, as also found in the tidal limestone depositions in the east margin of Ordos Basin [24]. The $\mathrm{Sr} / \mathrm{Ba}$ values in the Shanxi samples were relatively concentrated, and the sedimentary environment was relatively stable (Figure 3).

5.4. Paleoproductivity. Productivity refers to the amount of organic matter produced by a biological organism in a specific unit of time in a specific area unit. Paleoproductivity refers to the rate at which ancient marine organisms fixed energy in the energy cycle [71-74]. Phosphorus is mainly transferred to sediments in the form of organic bonds, most of which are released during the process of remineralization. The long-term retention of phosphorus in sediments requires adsorption on the $\mathrm{FeOOH}$ phase and precipitation as an autogenous phosphate mineral $[75,76]$. Phosphorus is an important index to evaluate marine paleoproductivity [7678]. In order to avoid the dilution effect of sediment organic matter and authigenic minerals on the phosphorus content in terrigenous clastic rocks, the $\mathrm{P} / \mathrm{Ti}$ ratio can be used to characterize the nutrient status of the ocean [76]. The P/Ti ratio of the Taiyuan Formation was 0.04 0.26 (mean 0.11), and that of the Shanxi Formation was 0.09 0.46 (mean 0.18) (Table 2), close to post-Archean Australian shale (PAAS) (0.13) and average pelagic clay (0.33), but significantly lower than those (2-8) associated with regions of elevated productivity in the modern equatorial Pacific [79]. This shows that the paleoproductivity of the marine- 

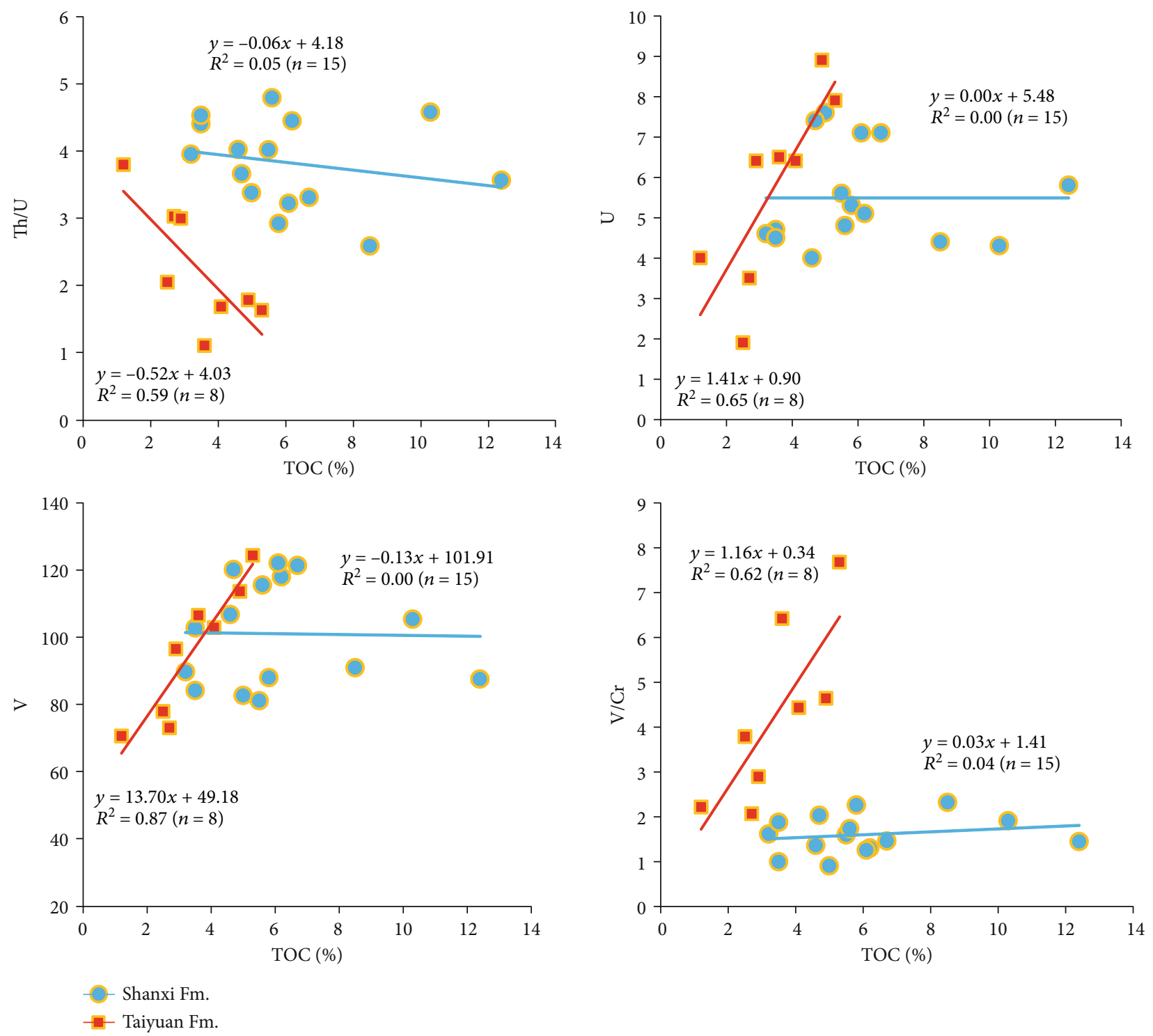

Figure 5: Crossplots of TOC content versus redox proxies (Th/U, U, V, and V/Cr) of the samples in the Taiyuan and Shanxi Formations.

continental transitional shale is poor, and the paleoproductivity increases gradually from Taiyuan Formation to Shanxi Formation. There is a positive correlation between the TOC and $\mathrm{P} / \mathrm{Ti}$ ratios of the Taiyuan and Shanxi Formations $\left(R^{2}=0.40\right.$, Figure 6$)$, indicating that paleoproductivity is one of the reasons for the high TOC.

The element Ba can also indicate paleoproductivity. Barite $\left(\mathrm{BaSO}_{4}\right)$ was deposited by combining $\mathrm{Ba}^{2+}$ in the marine environment with high concentration of $\mathrm{SO}_{4}{ }^{2-}$ on the surface of decaying organic matter. This results in a positive correlation between $\mathrm{Ba}$ accumulation rate and primary productivity $[73,80-82]$. The $\mathrm{Ba} / \mathrm{Al}$ ratio can be used to qualitatively evaluate paleoproductivity [83], and $\mathrm{Al}$ can be used as the denominator to eliminate the dilution effect of other components $[38,84]$. The $\mathrm{Ba} / \mathrm{Al}$ ratio of the Taiyuan Formation is 1 to 68 (average 22), and the $\mathrm{Ba} / \mathrm{Al}$ ratio of the Shanxi Formation is 2 to 102 (average 46) (Table 2). These values are lower than stratified sediments in the central California continental margin (100-200) [83], indicating a lower paleoproductivity of marine-continental transition shale.

5.5. Controls on the Accumulation of Organic Matter. The transitional sediments are affected by both the river and the marine environment; the accumulation of organic matter is the result of a combination of factors and is a complex physicochemical process [85]. In terms of productivity factors, paleoclimate contributed to plant abundance and rock weathering in the hydrocarbon source region. On the one hand, clastic flow provides abundant organic matter (plant debris); on the other hand, it serves as diluent of organic matter. The paleoproductivity during shale deposition directly controls the abundance of organic matter. In terms of preservation factors, the reduction of oxygen content in bottom water provides good conditions for the preservation of 


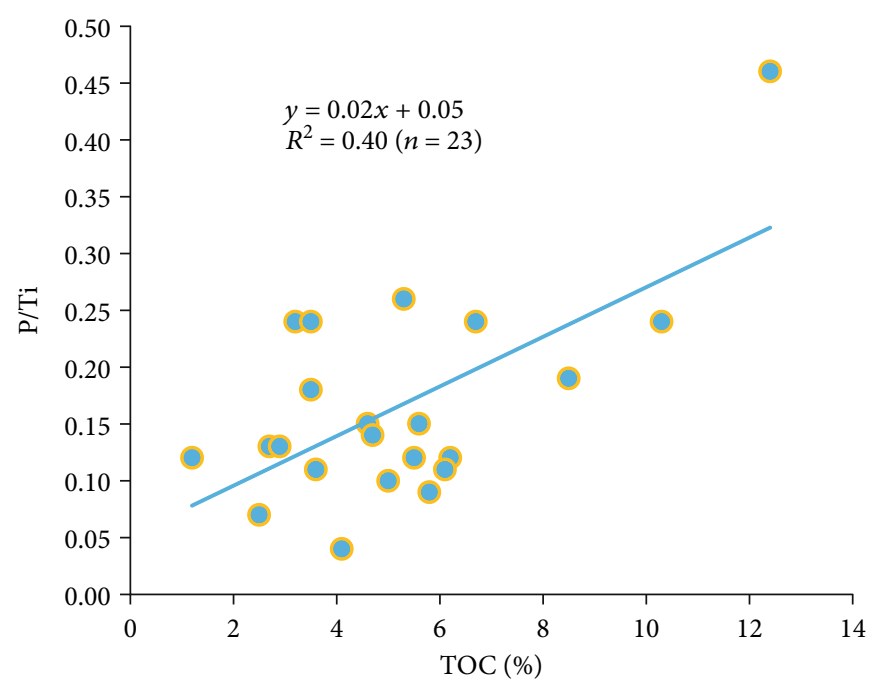

Figure 6: Crossplots of TOC content versus paleoproductivity proxies (P/Ti) of the samples in the Taiyuan and Shanxi Formations.

organic matter, and the deposition rate is also conducive to the accumulation of organic matter [85].

As noted earlier, during the deposition of the Taiyuan Formation shale, the paleoclimate is cold and arid; the sedimentary environment was a dysoxic-oxic depositional environment. The vertical variation trends of TOC and redox indicators are very consistent (Figure 3), which indicates that the decreasing oxygen content responded to the increasing TOC. There are positive correlations between the TOC and $\mathrm{U}, \mathrm{V}$, and $\mathrm{V} / \mathrm{Cr}\left(R^{2}=0.65,0.87\right.$, and 0.62 , respectively). These results indicate that the dysoxic conditions of the bottom water preservation environment were the key factor that contributed to the accumulation of organic matter for the Taiyuan Formation shale. Additionally, there is a weak positive correlation between the CIA and TOC $\left(R^{2}=0.10\right)$, meaning that the warm and humid paleoclimate also had a certain contribution to the enrichment of the organic matter.

For the Shanxi Formation shale, the paleoclimate was opposite of that for the Taiyuan Formation (cold and arid); the sedimentary environment was a relatively oxic delta system. The indicators of redox and paleoproductivity have no relationship with the TOC, indicating that the increasing oxygen content that leads to the redox conditions did not influence the organic matter preservation. Meanwhile, there is a positive correlation between the CIA and TOC $\left(R^{2}=0.44\right)$, indicating the paleoclimate contributed to the accumulation of organic matter in the Shanxi Formation shale. Because the delta depositional zone is closer to the provenance terrains, the warm and humid climate promoted land-based plant growth, which provided enough organic matter.

\section{Conclusions}

Based on the comprehensive analysis of petrology, total organic carbon, organic carbon isotopes, major elements, and trace elements, the constraints are provided for the climatic-oceanic environment and the deposition of organic-rich shales on the east margin of the Ordos Basin across the Upper Carboniferous-Lower Permian transition, with the following preliminary conclusions:

(1) Organic-rich shale of the Taiyuan Formation is deposited in the environment of a dysoxic-oxic depositional condition. There are significant positive correlations between TOC and redox indicators $(\mathrm{V}, \mathrm{U}$, and $\mathrm{V} / \mathrm{Cr})\left(R^{2}=0.65,0.87\right.$, and 0.62 , respectively. However, there is a weak positive relationship between TOC and CIA $\left(R^{2}=0.10\right)$. This indicates that the dysoxic bottom water conditions played a dominant role in the enrichment of organic matter

(2) Organic-rich shale of the Shanxi Formation is deposited in a relatively oxic delta system with humid and warm climate. Combined with the positive correlation between TOC and CIA $\left(R^{2}=0.44\right)$, it indicates that the warm and humid climate under oxidizing environment and high sedimentation rate jointly controlled the enrichment of organic matter

(3) The paleoproductivity proxies show a poor paleoproductivity of the Taiyuan and Shanxi Formation shale with a positive correlation between the TOC and P/Ti ratio $\left(R^{2}=0.40\right)$, which indicates that the paleoproductivity has certain influence on the enrichment of organic matter during deposition of the marinecontinental transitional shale

\section{Data Availability}

Data are available on request.

\section{Conflicts of Interest}

The authors declare that they have no conflicts of interest. 


\section{Acknowledgments}

This work was financially supported by the Second Tibetan Plateau Scientific Expedition and Research (STEP) Program (Grant No. 2019QZKK0707), the National Key R\&D Program of China (Grant No. 2017YFA0604803), the Chinese Academy of Sciences Key Project (Grant No. XDB26020302), the National Natural Science Foundation of China (Grant Nos. 41831176, 41902028, and 41972030), the CAS "Light of West China" Program, and the Key Laboratory Project of Gansu (Grant No. 1309RTSA041).

\section{References}

[1] K. A. Bowker, "Barnett shale gas production, Fort Worth Basin: issues and discussion," AAPG Bulletin, vol. 91, no. 4, pp. 523-533, 2007.

[2] D. M. Jarvie, R. J. Hill, T. E. Ruble, and R. M. Pollastro, "Unconventional shale-gas systems: the Mississippian Barnett Shale of north-central Texas as one model for thermogenic shale-gas assessment," AAPG Bulletin, vol. 91, no. 4, pp. 475-499, 2007.

[3] J. Q. Tan, P. Weniger, B. Krooss et al., "Shale gas potential of the major marine shale formations in the Upper Yangtze platform, South China, part II: methane sorption capacity," Fuel, vol. 129, pp. 204-218, 2014.

[4] J. Q. Tan, B. Horsfield, R. Fink et al., "Shale gas potential of the major marine shale formations in the Upper Yangtze platform, South China, part III: mineralogical, lithofacial, petrophysical, and rock mechanical properties," Energy \& Fuels, vol. 28, no. 4, pp. 2322-2342, 2014.

[5] J. Q. Tan, B. Horsfield, N. Mahlstedt et al., "Natural gas potential of Neoproterozoic and lower Palaeozoic marine shales in the Upper Yangtze platform, South China: geological and organic geochemical characterization," International Geology Review, vol. 57, no. 3, pp. 305-326, 2015.

[6] X. Tang, J. Zhang, X. Wang et al., "Shale characteristics in the southeastern Ordos Basin, China: implications for hydrocarbon accumulation conditions and the potential of continental shales," International Journal of Coal Geology, vol. 128-129, pp. 32-46, 2014.

[7] J. Q. Tan, B. Horsfield, N. Mahlstedt et al., "Physical properties of petroleum formed during maturation of Lower Cambrian shale in the upper Yangtze platform, South China, as inferred from phasekinetics modelling," Marine and Petroleum Geology, vol. 48, pp. 47-56, 2013.

[8] H. Bu, Y. Ju, J. Tan, G. Wang, and X. Li, "Fractal characteristics of pores in non-marine shales from the Huainan coalfield, eastern China," Journal of Natural Gas Science and Engineering, vol. 24, pp. 166-177, 2015.

[9] P. N. K. de Silva, S. Simons, P. Stevens, and L. Philip, “A comparison of North American shale plays with emerging nonmarine shale plays in Australia," Marine and Petroleum Geology, vol. 67, pp. 16-29, 2015.

[10] S. Jiang, X. L. Tang, D. S. Cai et al., "Comparison of marine, transitional, and lacustrine shales: a case study from the Sichuan Basin in China," Journal of Petroleum Science and Engineering, vol. 150, pp. 334-347, 2017.

[11] C. N. Zou, D. Z. Dong, S. J. Wang et al., "Geological characteristics and resource potential of shale gas in China," Petroleum
Exploration and Development, vol. 37, no. 6, pp. 641-653, 2010.

[12] C. N. Zou, D. Z. Dong, and H. Yang, "Conditions of shale gas accumulation and exploration practices in China," Natural Gas Industry, vol. 31, no. 12, pp. 26-39, 2011.

[13] H. B. Song, H. L. Wang, F. Wang, R. Guo, and B. Hu, "Ichnofossils and ichnofabrics in the lower Permian Taiyuan Formation of north China basin," Geodinamica Acta, vol. 28, no. 1-2, pp. 37-52, 2015.

[14] D. Costa, J. Jesus, D. Branco, A. Danko, and A. Fiúza, "Extensive review of shale gas environmental impacts from scientific literature (2010-2015)," Environmental Science and Pollution Research, vol. 24, no. 17, pp. 14579-14594, 2017.

[15] S. Jiang, Z. Y. Xu, Y. L. Feng et al., "Geologic characteristics of hydrocarbon-bearing marine, transitional and lacustrine shales in China," Journal of Asian Earth Sciences, vol. 115, pp. 404-418, 2016.

[16] C. Yang, et al.J. Zhang, X. Wang et al., "Nanoscale pore structure and fractal characteristics of a marine-continental transitional shale: a case study from the lower Permian Shanxi shale in the southeastern Ordos Basin, China," Marine and Petroleum Geology, vol. 88, pp. 54-68, 2017.

[17] J. Li, S. H. Tang, S. H. Zhang et al., "Characterization of unconventional reservoirs and continuous accumulations of natural gas in the Carboniferous-Permian strata, mid-eastern Qinshui basin, China," Journal of Natural Gas Science and Engineering, vol. 49, pp. 298-316, 2018.

[18] A. M. Martini, L. M. Walter, T. C. Ku, J. M. Budai, J. C. McIntosh, and M. Schoell, "Microbial production and modification of gases in sedimentary basins: a geochemical case study from a Devonian shale gas play, Michigan basin," AAPG Bulletin, vol. 87, no. 8, pp. 1355-1375, 2003.

[19] S. M. Rimmer, "Geochemical paleoredox indicators in DevonianMississippian black shales, central Appalachian Basin (USA)," Chemical Geology, vol. 206, no. 3-4, pp. 373-391, 2004.

[20] Y. Wang, C. Jie, L. Hu, and Y. Zhu, "Sedimentary environment control on shale gas reservoir: a case study of Lower Cambrian Qiongzhusi Formation in the Middle Lower Yangtze area," Journal of China Coal Society, vol. 38, no. 5, pp. 845-850, 2013.

[21] Y. Li, D. Tang, D. Elsworth, and H. Xu, "Characterization of coalbed methane reservoirs at multiple length scales: a crosssection from southeastern Ordos Basin, China," Energy \& Fuels, vol. 28, no. 9, pp. 5587-5595, 2014.

[22] Y. Li, et al.C. Zhang, D. Tang et al., "Coal pore size distributions controlled by the coalification process: an experimental study of coals from the Junggar, Ordos and Qinshui basins in China," Fuel, vol. 206, pp. 352-363, 2017.

[23] C. Zou, L. Hou, S. Hu et al., "Prospect of ultra-deep petroleum onshore China," Energy Exploration \& Exploitation, vol. 32, no. 1, pp. 19-40, 2014.

[24] Y. Li, et al.D. Tang, P. Wu et al., "Continuous unconventional natural gas accumulations of Carboniferous-Permian coalbearing strata in the Linxing area, northeastern Ordos basin, China," Journal of Natural Gas Science and Engineering, vol. 36, pp. 314-327, 2016.

[25] Y. Duan, et al.C. Y. Wang, C. Y. Zheng, B. X. Wu, and G. D. Zheng, "Geochemical study of crude oils from the Xifeng oilfield of the Ordos basin, China," Journal of Asian Earth Sciences, vol. 31, no. 4-6, pp. 341-356, 2008.

[26] X. W. Feng, N. Zhang, X. T. Chen, L. Gong, C. Lv, and Y. Guo, "Exploitation contradictions concerning multi-energy 
resources among coal, gas, oil, and uranium: a case study in the Ordos Basin (western north China Craton and southern side of Yinshan mountains)," Energies, vol. 9, no. 2, p. 119, 2016.

[27] Y. T. Yang, W. Li, and L. Ma, "Tectonic and stratigraphic controls of hydrocarbon systems in the Ordos basin: a multicycle cratonic basin in central China," AAPG Bulletin, vol. 89, no. 2, pp. 255-269, 2005.

[28] W. W. Yang, G. D. Liu, and Y. Feng, "Geochemical significance of $17 \alpha(\mathrm{H})$-diahopane and its application in oil-source correlation of Yanchang formation in Longdong area, Ordos basin, China," Marine and Petroleum Geology, vol. 71, pp. 238-249, 2016.

[29] T. W. Zhang, G. S. Ellis, S. C. Ruppel, K. Milliken, and R. Yang, "Effect of organic-matter type and thermal maturity on methane adsorption in shale-gas systems," Organic Geochemistry, vol. 47, pp. 120-131, 2012.

[30] W. Ding, D. Zhu, J. Cai, M. Gong, and F. Chen, “Analysis of the developmental characteristics and major regulating factors of fractures in marine-continental transitional shale-gas reservoirs: a case study of the Carboniferous-Permian strata in the southeastern Ordos Basin, Central China," Marine and Petroleum Geology, vol. 45, pp. 121-133, 2013.

[31] W. Shejiao, L. Denghua, L. Jianzhong, D. Dazhong, Z. Wenzheng, and M. Jun, "Exploration potential of shale gas in the Ordos Basin," Natural Gas Industry, vol. 31, no. 12, pp. 40-46, 2011.

[32] Z. Zhang, K. Sun, and J. Yin, "Sedimentology and sequence stratigraphy of the Shanxi Formation (Lower Permian) in the northwestern Ordos Basin, China: an alternative sequence model for fluvial strata," Sedimentary Geology, vol. 112, no. 1-2, pp. 123-136, 1997.

[33] D. T. Yan, H. Wang, Q. L. Fu, Z. Chen, J. He, and Z. Gao, "Organic matter accumulation of Late Ordovician sediments in North Guizhou Province, China: sulfur isotope and trace element evidences," Marine and Petroleum Geology, vol. 59, pp. 348-358, 2015.

[34] S. R. Taylor and S. M. McLennan, The continental crust: its composition and evolution, Blackwell Scientific Publications, London, 1985.

[35] C. M. Fedo, G. M. Young, and H. W. Nesbitt, "Paleoclimatic control on the composition of the Paleoproterozoic Serpent formation, Huronian Supergroup, Canada: a greenhouse to icehouse transition," Precambrian Research, vol. 86, no. 3-4, pp. 201-223, 1997.

[36] G. M. Young and H. Wayne Nesbitt, "Paleoclimatology and provenance of the glaciogenic Gowganda formation (Paleoproterozoic), Ontario, Canada: a chemostratigraphic approach," Geological Society of America Bulletin, vol. 111, no. 2, pp. 264-274, 1999.

[37] Y. Detian, C. Daizhao, W. Zhuozhuo, L. jing, Y. Xiangrong, and Z. Bao, "Climatic and oceanic controlled deposition of Late Ordovician-Early Silurian black shales on the North Yangtze platform, South China," Marine and Petroleum Geology, vol. 110, pp. 112-121, 2019.

[38] Y. Li, Z. Wang, Q. Gan, X. Niu, and W. Xu, "Paleoenvironmental conditions and organic matter accumulation in Upper Paleozoic organic-rich rocks in the east margin of the Ordos Basin, China," Fuel, vol. 252, pp. 172-187, 2019.

[39] C. Chen, C. L. Mu, K. K. Zhou et al., "The geochemical characteristics and factors controlling the organic matter accumulation of the Late Ordovician-Early Silurian black shale in the
Upper Yangtze Basin, South China," Marine and Petroleum Geology, vol. 76, pp. 159-175, 2016.

[40] H. W. Nesbitt and G. M. Young, "Early Proterozoic climates and plate motions inferred from major element chemistry of lutites," Nature, vol. 299, no. 5885, pp. 715-717, 1982.

[41] F. Martinez-Ruiz, M. Kastner, D. Gallego-Torres, M. RodrigoGámiz, V. Nieto-Moreno, and M. Ortega-Huertas, "Paleoclimate and paleoceanography over the past 20,000 yr in the Mediterranean Sea Basins as indicated by sediment elemental proxies," Quaternary Science Reviews, vol. 107, pp. 25-46, 2015.

[42] D. D. Bussan, C. A. Ochs, C. R. Jackson, T. Anumol, S. A. Snyder, and J. V. Cizdziel, "Concentrations of select dissolved trace elements and anthropogenic organic compounds in the Mississippi River and major tributaries during the summer of 2012 and 2013," Environmental monitoring and assessment, vol. 189, no. 2, 2017.

[43] H. Li, A. Shi, M. Li, and X. Zhang, "Effect of pH, temperature, dissolved oxygen, and flow rate of overlying water on heavy metals release from storm sewer sediments," Journal of Chemistry, vol. 2013, Article ID 434012, 11 pages, 2013.

[44] S. Joussaume and J. Jouzel, "Paleoclimatic tracers: an investigation using an atmospheric general circulation model under ice age conditions. 2. Water isotopes," Journal of Geophysical Research: Atmospheres, vol. 98, no. D2, pp. 2807-2830, 1993.

[45] A. Lerman, Lakes: Chemistry, Geology, Physics, Springer-Verlag, New York, Heidelberg, Berlin, 1978.

[46] H. Li, G. Liu, R. Sun, J. Chen, B. Wu, and C. Chou, "Relationships between trace element abundances and depositional environments of coals from the Zhangji coal mine, Anhui Province, China," Energy Exploration \& Exploitation, vol. 31, no. 1, pp. 89-107, 2013.

[47] G. Hofer, M. Wagreich, and S. Neuhuber, "Geochemistry of fine-grained sediments of the upper Cretaceous to Paleogene Gosau Group (Austria, Slovakia): implications for paleoenvironmental and provenance studies," Geoscience Frontiers, vol. 4, no. 4, pp. 449-468, 2013.

[48] B. M. Sarki Yandoka, W. H. Abdullah, M. B. Abubakar, M. H. Hakimi, and A. K. Adegoke, "Geochemical characterisation of early cretaceous lacustrine sediments of Bima formation, Yola sub-basin, Northern Benue trough, NE Nigeria: organic matter input, preservation, paleoenvironment and palaeoclimatic conditions," Marine and Petroleum Geology, vol. 61, pp. 8294, 2015.

[49] B. Jones and D. A. C. Manning, "Comparison of geochemical indices used for the interpretation of palaeoredox conditions in ancient mudstones," Chemical Geology, vol. 111, no. 1-4, pp. 111-129, 1994.

[50] N. Tribovillard, T. J. Algeo, T. Lyons, and A. Riboulleau, "Trace metals as paleoredox and paleoproductivity proxies: an update," Chemical Geology, vol. 232, no. 1-2, pp. 12-32, 2006.

[51] H. C. Jenkyns, A. J. Dickson, M. Ruhl, and S. H. J. M. Boorn, "Basalt-seawater interaction, the Plenus Cold Event, enhanced weathering and geochemical change: deconstructing Oceanic Anoxic Event 2 (Cenomanian-Turonian, Late Cretaceous)," Sedimentology, vol. 64, no. 1, pp. 16-43, 2017.

[52] J. C. Horne, J. C. Ferm, F. T. Caruccio, and B. P. Baganz, "Depositional models in coal exploration and mine planning in Appalachian region," AAPG Bulletin, vol. 62, no. 12, pp. 2379-2411, 1978. 
[53] P. B. Wignall, Black Shales, Clarendon Press, New York, Oxford University Press, Oxford, 1994.

[54] F. Galarraga, K. Reategui, A. Martïnez, M. Martínez, J. F. Llamas, and G. Márquez, "V/Ni ratio as a parameter in palaeoenvironmental characterisation of nonmature mediumcrude oils from several Latin American basins," Journal of Petroleum Science and Engineering, vol. 61, no. 1, pp. 9-14, 2008.

[55] M. A. Arthur and B. B. Sageman, "Marine black shales: depositional mechanisms and environments of ancient deposits," Annual Review of Earth and Planetary Sciences, vol. 22, no. 1, pp. 499-551, 1994.

[56] S. Neumeister, T. J. Algeo, A. Bechtel, H. J. Gawlick, R. Gratzer, and R. F. Sachsenhofer, "Redox conditions and depositional environment of the Lower Jurassic Bächental bituminous marls (Tyrol, Austria)," Austrian Journal of Earth Sciences: An International Journal of the Austrian Geological Society, vol. 109, no. 2, pp. 142-159, 2016.

[57] J. R. Hatch and J. S. Leventhal, "Relationship between inferred redox potential of the depositional environment and geochemistry of the Upper Pennsylvanian (Missourian) Stark Shale Member of the Dennis Limestone, Wabaunsee County, Kansas, U.S.A," Chemical Geology, vol. 99, no. 1-3, pp. 65-82, 1992.

[58] R. O. Hallberg, "A geochemical method for investigation of palaeoredox conditions in sediments," Ambio Special Report, vol. 4, pp. 139-147, 1976.

[59] M. Öztürk, “Trends of trace metal (Mn, Fe, Co, Ni, Cu, Zn, Cd and $\mathrm{Pb}$ ) distributions at the oxic-anoxic interface and in sulfidic water of the Drammensfjord," Marine Chemistry, vol. 48, no. 3-4, pp. 329-342, 1995.

[60] K. J. Myers and P. B. Wignall, "Understanding Jurassic organicrich mudrocks-new concepts using gamma-ray spectrometry and palaeoecology: examples from the Kimmeridge Clay of Dorset and the Jet Rock of Yorkshire," in Marine Clastic Sedimentology, J. K. Leggett and G. G. Zuffa, Eds., Springer, Dordrecht, 1987.

[61] P. B. Wignall and R. J. Twitchett, "Oceanic anoxia and the end Permian mass extinction,” Science, vol. 272, no. 5265, pp. 1155-1158, 1996.

[62] H. Kimura and Y. Watanabe, "Oceanic anoxia at the Precambrian-Cambrian boundary," Geology, vol. 29, no. 11, pp. 995-998, 2001.

[63] P. Z. Abanda and R. E. Hannigan, "Effect of diagenesis on trace element partitioning in shales," Chemical Geology, vol. 230, no. 1-2, pp. 42-59, 2006

[64] A. Panahi, G. M. Young, and R. Rainbird, "Behavior of major and trace elements (including REE) during Paleoproterozoic pedogenesis and diagenetic alteration of an Archean granite near Ville Marie, Québec, Canada," Geochimica et Cosmochimica Acta, vol. 64, no. 13, pp. 2199-2220, 2000.

[65] P. E. Potter, N. F. Shimp, and J. Witters, "Trace elements in marine and fresh-water argillaceous sediments," Geochimica et Cosmochimica Acta, vol. 27, no. 6, pp. 669-694, 1963.

[66] C. T. W. Price and B. Norman, "Departure curves for computing paleosalinity from boron in illites and shales," AAPG Bulletin, vol. 47, pp. 833-841, 1963.

[67] F. A. Campbell and G. D. Williams, "Chemical composition of shales of Mannville Group (Lower Cretaceous) of Central Alberta, Canada," AAPG Bulletin, vol. 49, pp. 81-87, 1965.

[68] I. Banerjee and F. Goodarzi, "Paleoenvironment and sulfurboron contents of the Mannville (Lower Cretaceous) coals of southern Alberta, Canada," Sedimentary Geology, vol. 67, no. 3-4, pp. 297-310, 1990.
[69] Z. Chen, Z. Chen, and W. Zhang, "Quaternary stratigraphy and trace-element indices of the Yangtze Delta, Eastern China, with special reference to marine transgressions," Quaternary Research, vol. 47, no. 2, pp. 181-191, 1997.

[70] D. Stüben, U. Kramar, Z. Berner, W. Stinnesbeck, G. Keller, and T. Adatte, "Trace elements, stable isotopes, and clay mineralogy of the Elles II K-T boundary section in Tunisia: indications for sea level fluctuations and primary productivity," Palaeogeography, Palaeoclimatology, Palaeoecology, vol. 178, no. 3-4, pp. 321-345, 2002.

[71] P. Bernárdez, R. González-Álvarez, G. Francés, R. Prego, M. A. Bárcena, and O. E. Romero, "Late holocene history of the rainfall in the nw iberian peninsula-evidence from a marine record," Journal of Marine Systems, vol. 72, no. 1-4, pp. 366382, 2008.

[72] S. D. Schoepfer, J. Shen, H. Y. Wei, R. V. Tyson, E. Ingall, and T. J. Algeo, "Total organic carbon, organic phosphorus, and biogenic barium fluxes as proxies for paleomarine productivity," Earth Science Reviews, vol. 149, pp. 23-52, 2015.

[73] J. Shen, S. D. Schoepfer, Q. L. Feng et al., "Marine productivity changes during the end-Permian crisis and Early Triassic recovery," Earth Science Reviews, vol. 149, pp. 136-162, 2015.

[74] A. C. Stock, J. John, R. R. Rykaczewski et al., "Reconciling fisheries catch and ocean productivity," Proceedings of the National Academy of Sciences, vol. 114, no. 8, pp. E1441E1449, 2017.

[75] T. J. Algeo and E. Ingall, "Sedimentary Corg: P ratios, paleocean ventilation, and Phanerozoic atmospheric $\mathrm{pO}_{2}$," Palaeogeography Palaeoclimatology Palaeoecology, vol. 256, no. 3-4, pp. 130-155, 2007.

[76] T. J. Algeo, K. Kuwahara, H. Sano et al., "Spatial variation in sediment fluxes, redox conditions, and productivity in the Permian-Triassic Panthalassic Ocean," Palaeogeography, Palaeoclimatology, Palaeoecology, vol. 308, no. 1-2, pp. 6583, 2011.

[77] J. C. Latimer and G. M. Filippelli, "Eocene to Miocene terrigenous inputs and export production: geochemical evidence from ODP Leg 177, Site 1090," Palaeogeography, Palaeoclimatology, Palaeoecology, vol. 182, no. 3-4, pp. 151-164, 2002.

[78] F. Pujol, Z. Berner, and D. Stüben, "Palaeoenvironmental changes at the Frasnian/Famennian boundary in key European sections: chemostratigraphic constraints," Palaeogeography Palaeoclimatology Palaeoecology, vol. 240, no. 1-2, pp. 120-145, 2006.

[79] R. W. Murray, M. Leinen, and A. R. Isern, "Biogenic flux of Al to sediment in the central equatorial Pacific Ocean: evidence for increased productivity during glacial periods," Paleoceanography, vol. 8, no. 5, pp. 651-670, 1993.

[80] J. Dymond and R. Collier, "Particulate barium fluxes and their relationships to biological productivity," Deep-Sea Research Part II, vol. 43, no. 4-6, pp. 1283-1308, 1996.

[81] A. Paytan and E. M. Griffith, "Marine barite: recorder of variations in ocean export productivity," Deep-Sea Research Part II, vol. 54, no. 5-7, pp. 687-705, 2007.

[82] K. Liu, Q. L. Feng, J. Shen, M. Khan, and N. Planavsky, "Increased productivity as a primary driver of marine anoxia in the Lower Cambrian," Palaeogeography Palaeoclimatology Palaeoecology, vol. 491, pp. 1-9, 2018.

[83] W. E. Dean, J. V. Gardner, and D. Z. Piper, "Inorganic geochemical indicators of glacial-interglacial changes in productivity and anoxia on the California continental margin," 
Geochimica et Cosmochimica Acta, vol. 61, no. 21, pp. 45074518, 1997.

[84] T. J. Algeo and J. B. Maynard, "Trace-element behavior and redox facies in core shales of Upper Pennsylvanian Kansastype cyclothems," Chemical Geology, vol. 206, no. 3-4, pp. 289-318, 2004.

[85] S. X. Liu, C. F. Wu, T. Li, and H. C. Wang, "Multiple geochemical proxies controlling the organic matter accumulation of the marine-continental transitional shale: a case study of the Upper Permian Longtan Formation, western Guizhou, China," Journal of Natural Gas Science and Engineering, vol. 56, pp. 152-165, 2018. 